\title{
HUBUNGAN MEKANISME KOPING DENGAN KUALITAS HIDUP PADA PASIEN KANKER PAYUDARA
}

\author{
Wiwik Nurhikmah $^{1}$, Abdul Wakhid ${ }^{1}$, Rosalina $^{1}$ \\ ${ }^{\mathbf{1}}$ Prodi Keperawatan Fakultas Keperawatan, Universitas Ngudi Waluyo Semarang \\ Email: abdul.wakhid2010@gmail.com
}

\begin{abstract}
ABSTRAK
Penderita penyakit kanker mengalami peningkatan yang sangat signifikan termasuk kanker payudara yang menyebabkan kematian. Penyakit kanker payudara mempengaruhi dampak yang besar bagi penderitanya, sehingga dapat mempengaruhi kualitas hidup. Penurunan kualitas hidup yang tidak teratasi akan menghambat pengobatan yang akan menyebabkan kematian. Tujuan penelitian ini adalah untuk mengetahui hubungan antara mekanisme koping dengan kualitas hidup pada pasien kanker payudara. Desain penelitian ini deskriptif korerasional dengan pendekatan cross sectional. Populasi penelitian ini pasien kanker payudara dengan jumlah sampel 55 responden menggunakan teknik accidental sampling serta alat pengambilan data menggunakan Cancer Coping Questionnaire 21 dan WHOQoL-BREF. Analisis data yang digunakan uji chi square. Hasil penelitian menunjukkan bahwa mekanisme koping pasien kanker kategori adaptif $65,5 \%$, kualitas hidup pasien kanker payudara kategori buruk 52,7\%. Ada hubungan mekanisme koping dengan kualitas hidup pada pasien kanker payudara yang menjalani kemoterapi dengan $p$ value $0,048(\alpha=0,05)$. Sebaiknya pihak RS memfasilitasi kegiatan interaksi dengan sesama pasien kanker payudara agar dapat berbagi pengalaman tentang peningkatan kualitas hidup.
\end{abstract}

Kata Kunci : Mekanisme Koping, Kualitas Hidup, Pasien Kanker Payudara

\section{THE ROLE OF MENTAL HEALTH CADRES IN THE HANDLING OF MENTAL PATIENTS}

\begin{abstract}
Patients with cancer have a very significant increase including breast cancer that causes death. Breast cancer affects the greatest impact on the sufferer, thus affecting the quality of life. Decreased quality of life that is not resolved will inhibit treatment that will cause death. The purpose of this study was to determine the relationship between coping mechanism with quality of life in breast cancer patients. This research design is descriptive correlational with cross sectional approach. The population of this study was breast cancer patients with a sample of 55 respondents using accidental sampling technique and data collection tool using Cancer Coping Questionnaire 21 and WHOQoLBREF. Data analysis used chi square test. The results showed that the mechanism of coping cancer patients $65.5 \%$ adaptive category, quality of life of breast cancer patients bad category 52,7\%. There is a relationship of coping mechanism with quality of life in breast cancer patients who underwent chemotherapy with $p$ value $0,048(\alpha=0,05)$. Should the hospital facilitate interaction activities with fellow breast cancer patients in order to share experiences about improving the quality of life.
\end{abstract}

Keywords: Mechanism of Coping, Quality of Life, Breast Cancer Patients

\section{PENDAHULUAN}

Kanker merupakan sebuah penyakit yang datang seketika, tetapi membutuhkan proses yang lama untuk menggroti tubuh manusia. Penyakit kanker salah satu penyebab utama kematian di seluruh dunia dan yang paling di takuti. Fenomena pada penyakit kanker saat ini mengalami peningkatan yang sangat signifikan, dan setiap tahun diberbagai belahan dunia jumlah penderita kanker bertambah. Berdasarkan data dari World Health
Organisasi (WHO) kasus penderita kanker meningkat dari 1,4 juta menjadi 12,7 juta. Data GLOBOCAN, Internasional Agency for Research on Cancer (IARC) diketahui bahwa pada tahun 2012 terdapat 14.067.894 kasus baru kanker dan 8.201.575 kematian akibat kanker di seluruh dunia. Presentase kasus kanker tertinggi yaitu kanker payudara 43,3\%, kanker prostat 30,7\%, dan kanker paru 23,1\% (Kemenkes, 2016). Berdasarkan Riset kesehatan dasar (Riskesdas) tahun 2013 
prevalensi penyakit kanker di indonesia memiliki persentase 1,4 per seribu penduduk sama dengan 330 ribu orang. Dengan perincian menurut provinsi, posisi paling tinggi terdapat di DI Yogyakarta dengan 4,1\%, lalu di Jawa tengah dengan $2,1 \%$, diikuti oleh bali dengan $2 \%$, dan DKI Jakarta serta Bengkulu masingmasing $1,9 \%$. Insiden kanker payudara di indonesia masih menempati urutan teratas dari 10 kanker pada wanita yaitu 134 per 100.000 penduduk perempuan kanker payudara 40 per 100.000 di ikuti kanker leher rahim 17 per 100.000 dan kanker kolorektal 10 per 100.000 perempuan. Berdasarkan data Sistem Informasi Rumah sakit (SIRS) tahun 2010 kasus rawat inap kanker payudara $28,7 \%$ dan kanker leher rahim 12,8\% (Riskesdas, 2013).

Kanker payudara adalah keganasan yang berasal dari kelenjar, saluran kelenjar dan jaringan penunjang tidak termasuk kulit payudara. Sel sel kanker payudara dapat menyebar melalui aliran darah keseluruh tubuh. Sel kanker payudara dapat bersembunyi didalam tubuh selama bertahun - tahun dan tiba-tiba aktif menjadi tumor ganas atau kanker (Mulyani dan Nuryani, 2013). Kaum wanita cukup rentan terhadap serangan kanker, bertambahnya usia pada wanita semakin besar kemungkinan terserang kanker payudara. Wanita dengan umur 40 tahun keatas lebih sering terkena kanker yang disebut cancer age group. Hampir seluruh faktor kanker payudara berhubungan langsung maupun tidak langsung dengan estrogen yang tidak dipakai dan sisa dalam tubuh ataupun estrogen yang tidak diimbangi dengan progesteron. Faktor resiko kanker payudara meliputi umur, menarche, mengkonsumsi alkohol, aktivitas fisik, usia saat melahirkan anak pertama dan riwayat keluarga dengan kanker (Mangan, 2010)

Diagnosis kanker payudara mempengaruhi dampak yang besar bagi penderitanya, baik aspek fisik, psikologis, seksual dan aspek kehidupan lainnya. Hal tersebut dapat mempengaruhi kualitas hidup pada pasien kanker (Kurniawan dan Lugito, 2015). Kualitas hidup adalah perasaan dan pernyataan rasa puas seseorang individu akan kehidupan secara menyeluruh dan secara status mental orang mengakui bahwa individu tersebut hidup dalam kondisi yang nyaman, jauh dari ancaman dan secara adekuat memenuhi kebutuhan dasar. Kualitas hidup sangatlah penting bagi seseorang yang mempunyai kecacatan maupun penyakit terminal seperti kanker dan penyakit jantung merupakan pusat perhatian yang dapat mempengaruhi harapan hidup (Kaplan \& Saccuzzo, 2012).

Kualitas hidup seseorang dikatakan tercapai apabila seseorang mendapatkan hidup yang normal dan memiliki tingkat derajat kesehatan yang baik. Pengaruh derajat kesehatan seseorang yaitu faktor perilaku dan faktor lingkungn (fisik, psikologis, psikososial, dan spiritual). Indikator pada kualitas hidup terdiri dari pendapatan, perumahan, lingkungan, stabilitas sosial, kesehatan, pendidikan dan kesempatan kerja (Nursalam, 2016). Menurut Critiani, Tedjo, dan Martono (2012) mengatakan kualitas hidup seseorang pada indikator pendapatannya di pengaruhi dari semakin tinggi penghasilan akan semakin tinggi pula taraf hidupnya. Kualitas hidup dengan indikator kesehatan dicapai melalui kombinasi dari kesehatan fisik, mental, dan kesehatan ekonomi sosial. Indikator pendidikan semakin tinggi tingkat pendidikan yang dicapai maka kualitas hidupnya baik. Pekerjaan yang mempunyai penghasilan untuk memenuhi kebutuhannya, semakin tinggi penghasilannya maka kualitas hidup semakin meningkat. Kualitas hidup yang diukur pada lingkungan dan perumahan dilihat pada tempat tinggal yang layak, lingkungan yang bersih dan air yang bersih. Terakhir indikator kualitas hidup yang dinilai dari stabilitas sosial yaitu dukungan dan pengakuan yang positif dari lingkuannya maupun keluarga.

Perubahan kondisi psikologis yang timbul pada penderita kanker dapat disebabkan karena proses penyembuhan kanker yang harus dijalani. Kanker merupakan salah satu dari 4 jenis penyakit yaitu psikosomatik, infeksi, jantung dan termasuk penyakit kanker yang diduga mempengaruhi dampak psikis seseorang seperti emosi marah, stress, iri, cemburu, cemas, bersalah, malu, sedih dan berharap. Jika individu berada pada posisi stres manusia akan menggunakan satu atau lebih sumber koping yang tersedia (Slamet \& Markam, 2015).

Hasil penelitian yang yang dilakukan Rochayanti (2011) tentang analisis faktorfaktor yang mempengaruhi kualitas hidup pasien penyakit jantung koroner di Rumah 
Sakit PELNI Jakarta. Penelitian menunjukan depresi sebagai faktor yang paling berhubungan dengan kualitas hidup. Penelitian yang pernah dilakukan oleh Mualim dan Prasojo (2016) tentang hubungan mekanisme koping dengan kepatuhan pasien kanker payudara dalam menjalani kemoterapi di RSUD Kraton Kabupaten Pekalongan. Penelitian ini menunjukan ada hubungan antara mekanisme koping dengan kepatuhan pasien kanker payudara dalam menjalani kemoterapi. Responden yang tidak patuh menjalani kemoterapi 44,4\% menggunakan mekanisme koping maladaptif oleh karena itu dibutuhkan koping yang adaptif dalam menjalani kemoterapi.

Teori Hee-Chung (2008) dalam Ayu, Pratiwi, dan Nur (2015) menuturkan apabila strategi koping yang digunakan sesuai dapat mempengaruhi emosi atau pikiran seseorang untuk dapat mengurangi stressor yang dihadapi. Startegi koping yang baik dapat menghasilkan kualitas hidup yang lebih baik dan menghasilkan suatu tindakan yang positif. Sebaliknya, apabila strategi koping yang digunakan tidak sesuai dapat menghasilkan kualitas hidup yang buruk dan dapat mengalami distress psikologis yang berat. Mukwato, dkk, 2010 mengatakan strategi mekanisme koping yang baik ada empat yang meliputi (a) Dukungan sosial, (b) Spiritual, (c) sikap atau pemikiran yang positif, dan (d) mendapatkan informasi atau pendidikan.

Mekanisme koping adalah cara yang dilakukan oleh individu untuk beradaptasi terhadap stres, menyelesaikan masalah, penyesuaian diri terhadap perubahan, dan respon terhadap situasi yang mengancam jiwa (Stuart dan Sundeen, 2008). Mekanisme koping bersifat konstruktif ketika ansietas digunakan sebagai tanda peringatan dan individu menerimanya sebagai tantangan untuk meyelesaikan masalah. Dalam meningkatkan mekanisme koping dibutuhkan pemikiran aspek - aspek yang positif dan dukungan emosional oleh keluarga. Koping yang efektif akan membantu individu terbebas dari stres yang berkepanjangan. Setiap individu menggunakan koping berbeda untuk menghadapi masalah yang melibatkan perubahan dalam masyarakat dan sistem hidup dari kondisi yang dianggap tidak memuaskan kepada suatu keaadan yang lebih baik.

Hasil studi pendahuluan yang dilakukan pada tanggal 8 juni 2017. Berdasarkan hasil wawancara dengan 5 orang penderita kanker payudara didapatkan 3 mempunyai kualitas hidup yang kurang baik (mereka merasa stres, depresi, dan takut akan penyakit nya) karena tidak mendapat dukungan yang baik dari keluarganya dan 2 mempunyai kualitas hidup yang baik (meraka merasa tidak stres,depresi dan pasrah dengan penyakitnya), mendapatkan dukungan yang baik dari keluarganya dan memiliki pemikiran yang positif terhadap penyakitnya. Berdasarkan uraian latar belakang diatas, maka tujuan penelitian ini adalah Mengetahui hubungan mekanisme koping dengan kualitas hidup pada pasien kanker payudara.

\section{METODE}

Penelitian ini menggunakan desain deskriptif korerasional Pendekatan yang digunakan dalam penelitian ini adalah cross sectional, Penelitian dilakukan di Rumah sakit Kabupaten Semarang, pada tanggal 28 Agustus-28 September 2017. Populasi dalam penelitian ini adalah pasien kanker payudara di Rumah sakit Kensaras, sebanyak 118., jumlah sampel yang dibutuhkan dalam penelitian ini adalah 55 responden. Teknik sampling dalam penelitian ini adalah dengan cara accidental sampling. Alat ukur variabel mekanisme koping menggunakan Cancer Coping Questionnaire, sedangkan kualitas hidup menggunakan WHOQOL-BREF.

\section{HASIL}

1. Gambaran Mekanisme Koping Pasien Kanker

Tabel 1 .

Distribusi Frekuensi Berdasarkan Mekanisme Koping Pasien Kanker

\begin{tabular}{lcl}
\hline \multicolumn{1}{c}{ Mekanisme Koping } & $\mathrm{f}$ & $\%$ \\
\hline Mal adaptif & 19 & 34,5 \\
Adaptif & 36 & 65,5 \\
\hline Jumlah & 55 & 100,0 \\
\hline
\end{tabular}


2. Gambaran Kualitas Hidup Pasien Kanker Payudara di RS KenSaras Kab. Semarang Tabel 2.

Distribusi Frekuensi Berdasarkan Kualitas Hidup Pasien Kanker Payudara

\begin{tabular}{lcc}
\hline Kualitas hidup & f & $\%$ \\
\hline Buruk & 29 & 52,7 \\
Baik & 26 & 47,3 \\
\hline Total & 55 & 100 \\
\hline
\end{tabular}

3. Hubungan Mekanisme Koping dengan Kualitas Hidup pada Pasien Kanker Payudara

Tabel 3.

Hubungan Mekanisme Koping dengan Kualitas Hidup pada Pasien Kanker Payudara

\begin{tabular}{|c|c|c|c|c|c|c|c|c|}
\hline \multirow{3}{*}{ Mekanisme koping } & \multicolumn{6}{|c|}{ Kualitas hidup } & \multirow{3}{*}{$x^{2}$} & \multirow{3}{*}{$\mathrm{p}$ value } \\
\hline & \multicolumn{2}{|c|}{ Kurang } & \multicolumn{2}{|c|}{ Baik } & \multicolumn{2}{|c|}{ Total } & & \\
\hline & $\mathrm{f}$ & $\%$ & $f$ & $\%$ & $\mathrm{f}$ & $\%$ & & \\
\hline Mal adaptif & 14 & 73,7 & 5 & 26,3 & 19 & 100,0 & 3,911 & 0,048 \\
\hline Adaptif & 15 & 41,7 & 21 & 58,3 & 36 & 100,0 & & \\
\hline Jumlah & 29 & 52,7 & 26 & 47,3 & 55 & 100,0 & & \\
\hline
\end{tabular}

Berdasarkan hasil analisis hubungan mekanisme koping dengan kualitas hidup pada pasien kanker payudara diperoleh hasil bahwa responden dengan mekanisme koping mal adaptif sebanyak 19 orang dimana sebagian besar mempunyai kualitas hidup kategori kurang yaitu sebanyak 14 orang $(73,7 \%)$ lebih banyak dari pada yang mempunyai kualitas hidup kategori baik yaitu sebanyak 5 orang $(26,3 \%)$. Responden dengan mekanisme koping mal adaptif sebanyak 36 orang dimana sebagian besar mempunyai kualitas hidup kategori baik yaitu sebanyak 21 orang $(58,3 \%)$ lebih banyak dari pada yang mempunyai kualitas hidup kategori kurang yaitu sebanyak 15 orang $(41,7 \%)$.

Hasil uji chi square didapatkan nilai korelasi $(3,911)>\chi_{\text {tabel }}^{2}(3,84)$ dan $p$ value $0,048(\alpha=$ $0,05)$, maka dapat disimpulkan ada hubungan mekanisme koping dengan kualitas hidup pada pasien kanker payudara yang menjalani kemoterapi. Berdasarkan hasil analisis dengan menggunakan uji chi square diperoleh pula nilai Odds Ratio (OR) sebesar 3,920 artinya responden yang mempunyai mekanisme koping kategori adaptif berpeluang 3,920 kali mempunyai kualitas hidup kategori baik daripada responden yang mempunyai mekanisme koping kategori mal adaptif.

\section{PEMBAHASAN}

1. Gambaran Mekanisme Koping Pasien Kanker

Hasil penelitian menunjukkan mekanisme koping pasien kanker di RS KenSaras
Kabupaten Semarang kategori maladaptif yaitu sebanyak 19 dari 55 responden $(34,5 \%)$. Mekanisme koping maladaptif adalah mekanisme koping yang menghambat fungsi integrasi, memecah pertumbuhan, menurunkan otonomi dan cenderung menguasai lingkungan. Kategorinya adalah makan berlebihan atau tidak makan, bekerja berlebihan, menghindar. Mekanisme koping maladaptif memperlihatkan bahwa mereka berfokus pada kehilangan dan dalam pikiran mereka terbenam dalam masa lalu. Penekanan pada pengajarannya adalah untuk mencari alternatif, menentukan tujuan yang realistis dan mendukung pencapaian yang benar dan pencapaian yang kecil.

Mekanisme koping maladaptif merupakan suatu usaha yang dilakukan individu dalam menyelesaikan masalah akibat adanya stressor atau tekanan yang bersifat negatif, merugikan dan destruktif serta tidak dapat menyelesaikan masalah secara tuntas (Funnell, Gabrielle \& Karen, 2008). Mekanisme koping yang menghambat fungsi integrasi, memecah pertumbuhan, menurunkan otonomi dan cenderung menguasai lingkungan. Kategorinya adalah makan berlebihan/ tidak makan, bekerja berlebihan, dan lain-lain. Koping yang efektif menghasilkan adaptasi yang menetap yang merupakan kebiasaan baru dan perbaikan dari situasi yang lama, sedangkan koping yang tidak efektif berakhir dengan maladapatif yaitu perilaku yang menyimpang dari keinginan normatif dan dapat merugikan diri sendiri maupun orang lain atau lingkungan. Menurut Stuart dan Sundeen (2008), salah satu faktor 
yang mempengaruhi mekanisme koping diantaranya adalah faktor pengetahuan.

Penderita kanker payudara yang mempunyai keterbatasan dalam wawasan dan pengetahuan cenderung mengatasi masalah dengan koping yang maladaptif. Mereka mengatasi berdasarkan apa yang mereka pahami benar, namun pada kenyataannya tidak selamanya benar. Mereka takut atau malu jika harus mengumpulkan informasi atau bertanya kepada yang sudah memahaminya misalnya masalah kesehatan maka harus berkonsultasi dengan tenaga kesehatan seperti bidan desa, perawat atau dokter. Rendahnya informasi yang dikumpulkan tersebut menyebabkan pemahaman mereka terhadap suatu masalah juga rendah yang pada akhirnya menyebabkan keputusan ataupun pemacahan masalah yang diambil kurang tepat atau dapat dikatakan mal adaptif. Hal tersebut jika terjadi terus menerua maka akan merugikan penderita kanker payudara itu sendiri.

Pengetahuan merupakan hasil tahu dan terjadi setelah orang melakukan penginderaan terhadap suatu obyek tertentu. Penginderaan terjadi melalui panca indra manusia yakni melalui indra penglihatan, penciuman, rasa, raba. Pengetahuan atau kognitif merupakan domain sangat penting dalam membentuk tindakan seseorang (Notoadmojdo, 2010). Tingkat pengetahuan dan intelegensi seseorang merupakan salah satu sumber koping dalam mengatasi masalah dengan menggunakan cara yang berbeda, akhirnya sumber koping seseorang juga termasuk kekuatan identitas ego, jaringan sosial, keseimbangan kultural, menstabilkan system kepercayaan dan berorientasi pada pencegahan terhadap penyakit (Stuart dan Sundeen, 2008).

Hasil penelitian ini sesuai dengan penelitian dari Budianto (2008), tentang hubungan antara tingkat pengetahuan pasien tentang penyakit kusta terhadap mekanisme koping yang digunakan penderita kusta di Desa Banyumanis RT 03 dan RT 04 RW 09 Kecamatan Keling Kabupaten Jepara. Hasil analisis chi square menunjukkan ada hubungan antara tingkat pengetahuan pasien tentang penyakit kusta terhadap mekanisme koping yang digunakan penderita kusta di Desa Banyumanis RT 03 dan RT 04 RW 09
Kecamatan Keling Kabupaten Jepara, dengan $p$ value sebesar 0,000 $(\alpha=0,05)$.

Hasil penelitian menunjukkan mekanisme koping pasien kanker di RS KenSaras Kabupaten Semarang kategori adaptif yaitu sebanyak 36 dari 55 responden $(65,5 \%)$. Mekanisme koping adaptif adalah mekanisme koping yang mendukung fungsi integrasi, pertumbuhan, belajar dan mencapai tujuan. Kategorinya adalah berbicara dengan orang lain, memecahkan masalah secara efektif, teknik relaksasi, latihan seimbang dan aktivitas konstruktif. Mekanisme koping adaptif memungkinkan perubahan diri saat seseorang merenungkan pengalaman hidup dan pengetahuan yang sudah mereka peroleh selama bertahun-tahun. Mekanisme koping adaptif merupakan suatu usaha yang dilakukan individu dalam menyelesaikan masalah akibat adanya stressor atau tekanan yang bersifat positif, rasional dan konstruktif (Funnell, Gabrielle \& Karen, 2008).

Mekanisme koping yang mendukung fungsi terintegrasi, pertumbuhan, belajar, dan mencapai tujuan. Kategorinya adalah berbicara dengan orang lain, memecahkan masalah secara efektif, teknik relaksasi, latihan seimbang dan aktivitas konstruktif. Menurut Lazarus dan Folkman (1984, dalam Safaria dan Saputra, 2009), pada dasarnya mekanisme koping ada dua macam yaitu problem-focused coping dan emotional-focused coping, yaitu usaha yang kuat melalui pemikiran dan perilaku untuk mengurangi atau mereduksi tekanan berat dari luar apapun dan dari dalam diri sendiri sehingga dapat mencari solusi. Menurut Tamher dan Noorkasiani (2009), salah satu faktor yang mempengaruhi mekanisme koping diantaranya adalah faktor motivasi.

Motivasi merupakan suatu proses psikologis yang mencerminkan interaksi antara sikap, kebutuhan, persepsi dan keputusan terjadi pada seseorang. Motivasi sebagai proses persepsi psikologis timbul diakibatkan oleh faktor di dalam diri seseorang itu sendiri yang disebut faktor intrinsik atau faktor dari luar diri yang disebut faktor ekstrinsik (Wahjosumidjo, 2009). Adanya motivasi akan sangat membantu seseorang dalam menghadapi dan menyelesaikan masalah. Individu yang tidak mempunyai motivasi untuk menghadapi dan 
menyalesaikan masalah akan membentuk koping yang destruktif. Tiap-tiap kebutuhan dapat dicapai, maka individu termotivasi untuk mencari kebutuhan pada tahap yang lebih tinggi berikutnya, sehingga individu akan mempunyai kemampuan dalam memecahkan masalah (Tamher dan Noorkasiani, 2009).

Hasil penelitian ini sesuai dengan penelitian dari Sayful dan Nizmah (2014) tentang hubungan dukungan dan motivasi keluarga dengan mekanisme koping pada penderita kanker payudara pasca stroke yang pernah rawat jalan di RSUD Kraton Kabupaten Pekalongan. Hasil analisis data dengan menggunakan uji chi square menunjukkan ada hubungan dukungan dan motivasi keluarga dengan mekanisme koping pada penderita kanker payudara pasca stroke yang pernah rawat jalan di RSUD Kraton Kabupaten Pekalongan, dengan $p$ value sebesar 0,026 $(\alpha=$ $0,05)$.

2. Gambaran Kualitas Hidup Pasien Kanker Payudara yang Menjalani Kemoterapi

Hasil penelitian menunjukkan bahwa kualitas hidup pasien kanker payudara yang menjalani kemoterapi di Rumah Sakit KenSaras Kabupaten Semarang dalam kategori buruk yaitu sebanyak 29 dari 55 responden (52,7\%). Kualitas hidup merupakan keadaan yang menyatakan kepuasan batin dan kenyamanan hidup seseorang di dunia. Kualitas hidup ditentukan oleh delapan aspek kehidupan diantaranya pendidikan, karier, keuangan, ketenaran, cinta, keturunan, pembimbing dan kesehatan (Chandramulyana, 2007). Kualitas hidup pasien kanker payudara yang menjalani kemoterapi di Rumah Sakit Kensaras Kabupaten Semarang dalam kategori kurang disebabkan oleh faktor penyakit.

Pasien yang menderita kanker sering mengalami penurunan berat badan dalam kurun waktu yang singkat. Mal nutrisi dan cachexia merupakan gangguan gizi berat yang sering terjadi pada penderita kanker, sekitar $24 \%$ pada stadium dini dan lebih dari $80 \%$ pada stadium lanjut. Kondisi ini dapat menurunkan kualitas hidup penderitanya yang disebabkan kanker itu sendiri maupun terapinya. Pemeriksaan klinis oleh tenaga kesehatan yang diikuti dengan promosi dan edukasi tentang pengobatan yang baik pada akhirnya akan meningkatkan pencapaian tujuan dari deteksi dini yaitu menurunkan angka kematian dan meningkatkan kualitas hidup penderita kanker payudara (Rasjidi, 2010).

Hasil penelitian menunjukkan bahwa kualitas hidup pasien kanker payudara yang menjalani kemoterapi di Rumah Sakit Kensaras Kabupaten Semarang dalam kategori baik yaitu sebanyak 26 dari 55 responden $(47,3 \%)$. Kualitas hidup merupakan suatu kondisi yang menyatakan tingkat kepuasan secara batin, kenyamanan dan kebahagiaan hidup dalam arti seluas-luasnya. Selama masih hidup manusia tidak akan pernah berhenti menghadapi permasalahan dan kesulitan. Seseorang yang terbiasa menghambil hikmah dari suatu kesulitans hidup akan tercipta perasaan lebih tenang dan tentram (Jusup, 2010). Kualitas hidup pasien kanker payudara yang menjalani kemoterapi di Rumah Sakit Kensaras Kabupaten Semarang dalam kategori baik didukung oleh dukungan keluarga.

Dukungan keluarga akan mempengaruhi kesehatan secara fisik dan psikologis, dimana dukungan keluarga tersebut dapat diberikan melalui dukungan emosional, informasi ataupun memberikan nasihat. Dukungan keluarga terdiri dari dukungan instrumental, dukungan informasional, dukungan emosional, dukungan pengharapan dan dukungan harga diri yang diberikan sepanjang hidup pasien. Dukungan keluarga yang didapat oleh pasien gagal ginjal kronis yang menjalani terapi hemodialisa menyangkut dukungan dalam masalah finansial, mengurangi tingkat depresi dan ketakutan terhadap kematian serta pembatasan asupan cairan (Brunner \& Suddarth, 2008). Dukungan keluarga juga dapat mempengaruhi kepuasan seseorang dalam menjalani kehidupan sehari-hari termasuk kepuasan terhadap status kesehatannya (Rasjidi, 2010).

3. Hubungan Lama Kemoterapi dengan Kualitas Hidup Pasien Kanker Payudara yang Menjalani Kemoterapi

Berdasarkan hasil analisis hubungan mekanisme koping dengan kualitas hidup pada pasien kanker payudara diperoleh hasil bahwa responden dengan mekanisme koping mal adaptif sebanyak 19 orang dimana sebagian besar mempunyai kualitas hidup kategori kurang yaitu sebanyak 14 orang $(73,7 \%)$ lebih 
banyak dari pada yang mempunyai kualitas hidup kategori baik yaitu sebanyak 5 orang (26,3\%). Responden dengan mekanisme koping mal adaptif sebanyak 36 orang dimana sebagian besar mempunyai kualitas hidup kategori baik yaitu sebanyak 21 orang $(58,3 \%)$ lebih banyak dari pada yang mempunyai kualitas hidup kategori kurang yaitu sebanyak 15 orang $(41,7 \%)$.

Hasil uji statistik dengan menggunakan uji chi square didapatkan nilai korelasi $(3,911)>\chi^{2}$ tabel $(3,84)$ dan $p$ value $0,048(\alpha=0,05)$, maka dapat disimpulkan ada hubungan mekanisme koping dengan kualitas hidup pada pasien kanker payudara. Berdasarkan hasil analisis dengan menggunakan uji chi square diperoleh pula nilai Odds Ratio (OR) sebesar 3,920 artinya responden yang mempunyai mekanisme koping kategori adaptif berpeluang 3,920 kali mempunyai kualitas hidup kategori baik daripada responden yang mempunyai mekanisme koping kategori mal adaptif.

Jaringan payudara terdiri dari kelenjar susu (kelenjar pembuat air susu), saluran kelenjar (saluran air susu), dan jaringan penunjang payudara. Payudara yang sensitif terhadap pengaruh hormonal mengakibatkan payudara cenderung mengalami pertumbuhan neoplastik yang bersifat jinak maupun ganas. Pertumbuhan neoplastik yang bersifat ganas dapat berupa kanker. Kanker payudara paling banyak menyerang wanita, penyakit ini disebabkan karena terjadi pembelahan sel- sel tubuh secara tidak teratur sehingga pertumbuhan sel tidak dapat dikendalikan dan menjadi tumor (Savitri, dkk, 2015).

Menurut Mardiana, Ma'rifah, dan Rahmawati (2013) Seseorang yang menderita penyakit kanker payudara akan menunjukan kesadaran tinggi dalam memecahkan masalahnya. Dalam mengatasi stres nya individu memerlukan segala usaha untuk mengatasi stres akibat kondisi yang dialaminya. Mekanisme koping sangatlah penting untuk menyelesaikan masalah, menyesuaikan diri dari perubahan dan respon terhadap situasi yang mengancam. Masalah yang muncul pada penderita kanker payudara meliputi masalah psikososial, body image, penurunan harga diri, gangguan hubungan dengan pasangan yang dapat menurunkan kualitas hidup perempuan dengan kanker payudara (Nasir dan Munith, 2011).
Kualitas hidup yang berhubungan dengan kesehatan dapat diartikan sebagai respon emosi dari penderita terhadap aktivitas sosial, emosional, pekerjaan dan hubungan antara keluarga. Kualitas hidup yang baik pada pasien dengan kanker payudara sangat diperlukan untuk mempertahankan agar pasien mampu mendapatkan status kesehatan terbaik dan mempertahankan fungsi atau kemampuan fisiknya seoptimal mungkin (Rochmayanti, 2011).

Jaringan payudara tersebut terdiri dari kelenjar susu (kelenjar pembuat air susu), saluran kelenjar (saluran air susu) dan jaringan penunjang payudara Kanker payudara merupakan tumor ganas yang menyerang jaringan payudara (Mardiana, 2004). Setiap penderita kanker payudara penting dan patut untuk melakukan pengobatan terhadap kanker payudara. Pengobatan kanker payudara sangat tergantung pada jenis, lokasi dan tingkat penyebarannya. Pengobatan pada pasien kanker payudara ada beberapa jenis dan salah satunya adalah kemoterapi. Kemoterapi merupakan penggunaan obat-obatan khusus untuk mematikan sel-sel kanker (Yudissanta \& Ratna, 2012).

Menurut Breast Cancer Organization (2012), mengatakan bahwa efek samping yang akan muncul pada kemoterapi tergantung pada jumlah obat yang didapatkan, masa pengobatan dan keadaan kesehatan umum penderita. Efek kemoterapi yang paling umum terjadi seperti mual, muntah, kelelahan, anemia, diare, rambut rontok, infeksi, infertil, menopause, masalah kesuburan dan perubahan berat badan. Pasien kanker yang menjalani kemoterapi dapat mengalami perubahan dari berbagai aspek-aspek kehidupan yang akan berpengaruh terhadap kesehatan fisik, kesejahteraan psikologis, hubungan sosial dan dengan lingkungan. Dengan kata lain, hal tersebut juga akan berdampak pada kualitas hidup pasien (Skevington, Lotfy \& Connell, 2004).

Kualitas hidup yang berhubungan dengan kesehatan dapat diartikan sebagai respon emosi dari penderita terhadap aktivitas sosial, emosional, pekerjaan dan hubungan antara keluarga, rasa senang atau bahagia, adanya kesesuaian antara harapan dan kenyataan yang 
ada, adanya kepuasan dalam melakukan fungsi fisik, sosial dan emosional serta kemampuan mengadakan sosialisasi dengan orang lain (Silitonga 2007). Beberapa faktor yang mempengaruhi gambaran kualitas hidup pasien dibagi menjadi dua bagian. Bagian yang pertama adalah sosiodemografi yaitu jenis kelamin, umur, suku/ etnik, pendidikan, pekerjaan dan status perkawinan. Bagian kedua adalah medis yaitu stadium penyakit, dan penataklasanaan medis yang dijalani dan lama menjalani pengobatan medis (kemoterapi) (Desita, 2010).

Menurut Tjokronegoro (2006), pemberian kemoterapi tidak hanya diberikan sekali saja, namun diberikan secara berulang (berseri) artinya pasien menjalani kemoterapi setiap dua seri, tiga seri, ataupun empat seri dimana setiap seri terdapat proses pengobatan dengan kemoterapi diselingi dengan periode pemulihan kemudian dilanjutkan dengan periode pengobatan kembali dan begitu seterusnya sesuai dengan obat kemoterapi yang diberikan.

Menurut Ogce \& Ozkan (2008) menyatakan dampak fisik dan psikologis yang ditimbulkan akibat pemberian lama kemoterapi terkait dengan penurunan kemampuan dalam status fungsional selama menjalani kemoterapi. Semakin banyak lama pemberian kemoterapi maka akan semakin banyak sel kanker mengalami kerusakan dan kematian, demikian juga pada sel sehat dalam tubuh, setelah beberapa periode, satu sampai tiga minggu sel sehat pulih kembali namun mengalami kerusakan yang berarti sehingga akan mengalami penurunan fungsi dan ketahanan tubuh pasien juga akan menurun hal ini akan terus berlanjut pada pemberian kemoterapi berikutnya (Smeltzer \& Bare, 2007).

Tahap awal menjalani pengobatan (kemoterapi) pasien seolah-olah tidak menerima atas penyakitnya, marah dengan kejadian yang ada dan merasa sedih dengan kejadian yang dialami sehingga memerlukan penyesuaian diri yang lama terhadap lingkungan yang baru dan harus menjalani pengobatan tersebut (kemoterapi). Waktu yang diperlukan untuk beradaptasi masing-masing pasien berbeda lamanya, semakin lama pasien menjalani pengobatan (kemoterapi) adaptasi pasien semakin baik karena pasien telah mendapat pendidikan kesehatan atau informasi yang diperlukan semakin banyak dari petugas kesehatan (Sapri, 2008). Semakin lama pasien menjalani pengobatan (kemoterapi), maka semakin patuh pasien tersebut karena pasien sudah mencapai tahap accepted (menerima) dengan adanya pendidikan kesehatan dari petugas kesehatan yang pada akhirnya akan meningkatkan kualitas hidupnya (KublerRoss, 1998 dalam Sapri 2008).

\section{SIMPULAN DAN SARAN Simpulan}

Mekanisme koping pasien kanker kategori adaptif yaitu sebanyak 36 dari 55 responden $(65,5 \%)$. Kualitas hidup pasien kanker payudara kategori buruk yaitu sebanyak 29 dari 55 responden $(52,7 \%)$. Ada hubungan mekanisme koping dengan kualitas hidup pada pasien kanker payudara yang menjalani kemoterapi dengan $p$ value sebesar $0,048(\alpha=$ $0,05)$.

\section{Saran}

Sebaiknya pihak RS memfasilitasi kegiatan interaksi dengan sesama pasien kanker payudara agar dapat berbagi pengalaman tentang peningkatan kualitas hidup. Berupaya meningkatkan mutu pelayanan kesehatan pada pasien yang mengalami penyakit kanker dengan memberikan bimbingan spiritual sesuai dengan agama pasien secara kontinyu dan berkesinambungan bagi pasien rawat inap. Sedangkan untuk pasien rawat jalan dapat membentuk kelompok bagi penderita kanker dengan berbagai kegiatan positif misalnya rekreasi yang terjadwal sehingga dapat meningkatkan semangat hidup hingga kualitas hidup pasien. Pihak rumah sakit juga dapat menciptakan suasananya rekreasi di bangsal perawatan sehingga pasien merasa nyaman dan terhibur.

\section{DAFTAR PUSTAKA}

Ayu, S.R, Pratiwi, A \& Nur. 2015. Mekanisme Koping pada Pasien Terdiagnosa Kanker Paru di RS Islam Surakarta. Diakses pada tanggal 13 Maret 2017

Brunner \& Suddarth. 2008. Buku Ajar Keperawatan Medikal Bedah, edisi 8, volume 3. Jakarta : EGC 
Budiarto \& Anggraeni. 2008. Pengantar Epidemiologi II. Jakarta : Buku Kedokteran EGC

Chen, Rostia \& CancerHelps. 2012. Solusi Cerdas Mencegah dan Mengobati Kanker. Jakarta : PT.AgroMedika Pustaka

Desita, 2010. Hubungan Dukungan Keluarga dengan Kualitas Hidup Pasien Gagal Ginjal Kronis yang Menjalani Terapi Hemodialisa di RSUP Haji Adam Malik Medan. SKRIPSI. US

Kelliat, B. Anna. 2016. Prinsip dan Praktik Keperawatan Kesehatan Jiwa Stuart buku 1. Edisi Indonesia. Singapore : Elsevier Singapore Pte Ltd

Kemenkes RI. 2016. InfoDATIN Kanker Payudara

Kurniawan, Andre \& Lugito, N.T. 2015. Nutritional Status and Quality of Life in Breast Cancer Patients in Karawaci General Hospital. Diakses pada tanggal 06 April 2017

Makiyah, Sri Nabawiyati. 2011. Mutiara Medika. Yogyakarta : Aditya Medika

Mangan, Yellia. 2010. Solusi Sehat Mencegah dan Mengatasi Kanker. Jakarta : PT.AgroMedika Pustaka

Maramis. 2008. Catatan Ilmu Kedokteran Jiwa. Surabaya : Airlangga. University Press

Mardiana, Ma'rifah \& Rahmawati. 2013. Hubungan Mekanisme Koping dengan Kualitas Hidup Penderita Kanker Servik di RSUD Prof.dr. Margono Soekarjo Puwokerto. Diakses pada tanggal 13 Maret 2017

Mukwato, dkk. 2010. Stres and Coping Mechanisms Among Breast Cancer Patients and Family Caregivers. Diakses pada tanggal 06 April 2017

Mulyani, S.M \& Nuryani. 2013. Kanker Payudara dan PMS pada Kehamilan. Yogyakarta : Nuha Medika
Nasir \& Munith. 2011. Dasar - Dasar Keperawatan Jiwa. Jakarta : Salemba Medika

Notoatmodjo. 2010. Ilmu Perilaku Kesehatan. Jakarta : PT Rineka Cipta

Nursalam \& Kurniawati, N.D. 2007. Asuhan Keperawatan pada Pasien Terinfeksi HIV/AIDS. Jakarta : Salemba Medika

Potter \& Perry. 2010. Fundamental Keperawatan buku 3. Edisi 7. Jakarta : Salemba Medika

Prasojo, Sigit \& Mualim, F. 2016. Hubungan Mekanisme Koping dengan Kepatuhan Pasien Kanker Payudara dalam Menjalani Kemoterapi di RSUD Kraton Kaputen Pekalongan. Diakses pada tanggal 13 Maret 2017

Purwanto, Teguh. 2015. Buku Ajar Keperawatan Jiwa. Yogyakarta : PUSTAKA PELAJAR

Rahayu, Eny. 2010. Koping Ibu terhadap bayi BBLR yang Menjalani Perawatan Intensif di Ruang NICU. Diakses pada 29 April 2017

Rasjidi. 2010. 1000 Questions \& Answer Kanker pada Wanita. Jakarta : PT Elex Media Komputindo

Rasmun. 2004. Stres Koping dan Adaptasi Teori dan Pohon Masalah Keperawatan. Jakarta : Sagung Seto

Rikesdas. 2013. InfoDATIN Kanker Payudara

Rochmayanti. 2011. Analisis Faktor - Faktor yang Mempengaruhi Kualitas Hidup Pasien Penyakit Jantung Koroner di RS PELNI Jakarta. Diakses pada tangal 11 Maret 2017

Saccuzzo, D.P \& Kaplan, R.M. 2012. Pengukuran Psikologis Prinsip, Penerapan, dan Isu. Jakarta : Salemba Humanika

Savitri, Astrid dkk. 2015. Kupas Tuntas Kanker. Yogyakarta : Pustaka Baru Press 
Silalahi, W.A. 2014. Mekanisme Koping Pasien Kanker Payudara di RSUP Haji Adam Malik Medan. Diakses pada tanggal 29 Mei 2017

Siswanto. 2007. Kesehatan Mental, Konsep, Cakupan dan Perkembangannya. Yogyakarta : CV. Andi Offset

Slamet, I.S \& Sumarmo, M. Pengantar Psikolosgis Klinis. Jakarta : UI-Press

Stuart \& Sunden. 2008. Buku Saku Keperawatan Jiwa. Jakarta : EGC

Sugiyono. 2015. Metode Penelitian Kuantitatif, Kualitatif dan $R \& D$. Bandung: Alfabeta

Sunaryo. 2008. Psikologis untuk Keperawatan. Jakarta : EGC

Ventegodt, Kandel and Merrick, 2005. Aging and disability Research and clinical perspectives. Victoria, BC : Int Acad Press

Wasis. 2008. Pedoman Riset Praktik Untuk Profesi Perawat. Jakarta: EGC

World Health Organization. 2012. WHO : Quality Of Life-Bref (WHOQOL-BREF)

Yuliaw. 2009. Hubungan Karakteristik Individu dengan Kualitas Hidup Dimensi Fisik pasien Gagal Ginjal Kronik di RS Dr. Kariadi Semarang. Diakses pada tanggal 11 Maret 2017 